\title{
Effect of Flunixin Meglumine administration on seminal characteristics of male sheep and goat
}

\section{Efeito da administração de Flunixina Meglumine sobre as características seminais de machos ovinos e caprinos}

\author{
Maurício Francisco Vieira Neto ${ }^{1 *}$; Inti Campos Salles Rodrigues ${ }^{2}$; Jaqueline da \\ Silva Leles ${ }^{2}$; Érica Pinto de Araújo ${ }^{3}$; Aderson Martins Viana Neto ${ }^{4}$; Felipe Viana de \\ Carvalho $^{5}$; Maria Gorete Flores Salles ${ }^{6}$; Airton Alencar de Araújo ${ }^{7}$
}

\begin{abstract}
Testicular degeneration is a multifactorial process increasing the concentration of prostaglandins in seminal plasma. Both increase and decrease of these hormones tend to promote loss of seminal quality. Flunixin meglumine is a potent anti-inflammatory drug capable of modulating the production of prostaglandins and is widely used in female reproduction. However, it is rarely used in males with the same objective. Therefore, this study aimed to evaluate the effects of this drug on seminal quality of male lambs and goats with spermatic characteristics unfavorable for reproduction. To this end, a total of 15 breeding animals were evaluated, of which six goats and four sheep with poor seminal quality were selected according to the criteria established by the Brazilian College of Animal Reproduction (CBRA). Three semen samples were collected from each animal. Then, the flunixin meglumine treatment was initiated and ejaculates were collected at two different periods after the drug was administered (from day 21 until day 35 and from day 49 to day 63). Macroscopic and microscopic parameters were assessed in semen samples and scrotal circumference and percentages of sperm pathologies were measured and compared between the three periods. Data with normal distribution were analyzed using ANOVA at $5 \%$ probability, and comparisons between periods within the same species were performed using the Tukey test. An improvement was observed in the analyses of mass motility, percentage motility, and sperm vigor. Scrotal circumference had no variation. Concerning sperm pathologies, an increase in the number of normal spermatozoids was observed due to a significant reduction in minor and major defects, and the latter remained low even after the treatment was finished. Therefore, flunixin meglumine presented beneficial effects on seminal parameters of male goats and lamb with unfavorable spermatic characteristics. These findings indicate this drug may be used in the treating of males with testicular injuries or of breeders with reduced seminal quality due to advanced age.
\end{abstract}

Key words: Andrology. Animal Reproduction. Prostaglandins. Seminal Quality.

1 Discente de Mestrado, Programa de Pós-Graduação em Ciências Veterinárias, PPGCV, Universidade Estadual do Ceará, UECE, Fortaleza, CE, Brasil. E-mail: mauricio.macejo@hotmail.com

2 Mestres, Programa de Pós-Graduação em Ciências Veterinárias, PPGCV, UECE, Fortaleza, CE, Brasil. E-mail: inti.rodrigues@, yahoo.com.br; jaqueline.slekis@gmail.com

3 Discente de Mestrado, Programa de Pós-Graduação em Zootecnia, PPGZ, Universidade Federal do Ceará, UFC, Fortaleza, CE, Brasil. E-mail: erica araujo6@hotmail.com

4 Discente de Doutorado, Programa de Doutorado Integrado em Zootecnia, PDIZ, UFC, Fortaleza, CE, Brasil. E-mail: adersonv@, gmail.com

5 Discente de Graduação em Medicina Veterinária, UECE, Fortaleza, CE, Brasil. E-mail: felipevianadecarvalho@gmail.com

6 Prof ${ }^{a}$ Adjunta, Universidade da Integração Internacional da Lusofonia Afro-Brasileira, UNILAB, Redenção, CE, Brasil. E-mail: gorete@unilab.edu.br

7 Prof. Associado, Universidade Estadual do Ceará, UECE, Fortaleza, CE, Brasil. E-mail: airton.alencar@uece.br

* Author for corresponsdence

Received: Apr. 11, 2017 Approved: Aug. 04, 2017 


\section{Resumo}

A degeneração testicular é um processo multifatorial que leva ao aumento das prostaglandinas no plasma do ejaculado, sendo que tanto seu acréscimo quanto a redução baixam a qualidade seminal. A Flunixina Meglumine é um potente anti-inflamatório, capaz de modular a produção de prostaglandinas, amplamente difundido na reprodução de fêmeas, mas pouco utilizado em machos para esse fim. Por isso, esse trabalho buscou avaliar o efeito deste fármaco sobre a qualidade seminal de machos ovinos e caprinos que apresentem quadro espermático desfavorável à reprodução. Para tanto, um total de 15 reprodutores pertencentes à Universidade Federal do Ceará foram avaliados, dos quais foram selecionados seis bodes e quatro carneiros com sêmen de baixa qualidade, segundo os critérios do Colégio Brasileiro de Reprodução Animal (CBRA). Foram realizadas três colheitas prévias de cada animal, aplicado o tratamento com Flunixina Meglumine e, em seguida, foram colhidos ejaculados de dois momentos posteriores à aplicação do fármaco (do D21 ao D35 e do D49 ao D63). Os parâmetros espermáticos de natureza macro e microscópica, assim como a circunferência escrotal e o percentual de patologias espermáticas foram comparados entre os três momentos e os dados de distribuição normal foram avaliados por ANOVA a $5 \%$ de probabilidade e as comparações entre os momentos dentro de cada espécie quando significativa foram feitas pelo teste de Tukey. Houve melhora na motilidade massal, motilidade percentual e vigor espermático. Não ocorreu variação da circunferência escrotal e, no tocante às patologias espermáticas, observou-se um aumento no número de espermatozoides normais, devido a uma redução significativa de defeitos menores e maiores, sendo que estes permaneceram menores mesmo após cessar a influência do tratamento. Assim, a Flunixina Meglumine mostrou uma ação benéfica sobre os parâmetros seminais de machos ovinos e caprinos com quadro espermático desfavorável, sugerindo a indicação do fármaco para o tratamento de machos que passaram por injúrias testiculares diversas ou reprodutores com declínio da qualidade seminal devido à idade avançada.

Palavras-chave: Andrologia. Prostaglandinas. Qualidade Seminal. Reprodução Animal.

\section{Introduction}

Adult lamb presents better seminal parameters at four or five years of age than at one or two years of age (LYMBEROPOULOS; TSAKMAKIDIS; KHALIFA, 2010). Mandiki et al. (1998), reported better spermatic quality in 3-year-old lambs than in 2-year-old lamb. However, several conditions can weaken sperm quality and homeostasis in the reproductive tract, such as nutritional disorders, thermal stress, infectious and parasitic diseases and advanced age (MOREIRA, MOURA; ARAUJO, 2001; ARMENGOL et al., 2015).

Testicular degeneration is the main cause of infertility in males (ALVES, 2016) and is caused by factors influencing testicular thermoregulation and, consequently, the gonadal germinal epithelium (SANTOS; SIMPLÍCIO, 2000). During degeneration, tissues release membrane phospholipids, which, due to the activity of phospholipase-A, generate a number of fatty acids.
The most important of them is arachidonic acid, which becomes the main cause for prostaglandins in presence of cyclooxygenases (COX). Prostaglandins, a type of eicosanoid, are interesting to pharmacology due to their important biological functions, such as inflammatory processes, local blood flow and reproduction (PALERMO-NETO et al., 2014).

These eicosanoids are also found in seminal plasma. Lamb and goat ejaculates are filled with different types of eicosanoids, but the reduction of some of the prostaglandins levels is associated with low fertility in reproducers (MARLEY et al., 1997). However, an uncontrolled increase is also harmful, as exemplified in a study reported by Archbald et al. (1990), in which the level of $E_{2}$ prostaglandin was inversely linked to the capacity of acrosome reaction of lamb sperm cells.

Experimentally, the addition of $\mathrm{F}_{2 \alpha}$ prostaglandin in seminal plasma may cause fertility reduction in 
bulls and rabbits, due to acrosomal damage and early release of transaminases and lactate dehydrogenase. On the other hand, in lambs, there was no release of transaminases enzymes, which is related to this species' resistance to the eicosanoid (FAYED, 1996). In horses, the addition of this prostaglandin helps to maintain sperm motility and is a helpful resource for older animals (CEBİ ŞEN; AKCAY, 2015).

Non-steroidal anti-inflammatory drugs (NSAI) are useful pharmaceuticals for modulation of prostaglandin production since they inhibit COX (TASAKA, 2014). One prostaglandin, Flunixin Meglumine, has stood out due to its modulation activity in the production of $\mathrm{PGF}_{2 \alpha}$, which has been useful to extend the luteal phase in the estral cycle of sheep (AKÉ-LOPEZ et al., 2005) and to assist biotechniques, such as embryo transfer in bovines (CARDOSO, 2009) and to improve pregnancy rates in reproductive protocols of heifers (GUZELOGLU et al., 2007).

However, there are few papers in the literature analyzing this drug for reproductive purposes in males. Archbald et al. (1990) reported that its use in lambs can improve the capacity of acrosomal reactions, associated with PGE reduction. However, there is still little information on its impact on seminal quality. Therefore, considering the importance of the effects of prostaglandin in sperm activity and the lack of research involving the use of Flunixin Meglumine in the reproduction of male lamb and goats, the present study intends to evaluate the effect of this drug on the seminal quality of males of these species presenting spermatic characteristics unfavorable for reproduction.

\section{Material and Methods}

This experiment was approved by the Animal Use Ethics Committee (CEUA) of the University of the State of Ceará (UECE), process number $0533077 / 2016$.

\section{Location of experiment execution}

This study was executed in the Goats and Sheep sector of the Department of Animal Science, Federal University of Ceará (UECE). It is located in the Pici Campus, in the city of Fortaleza - Ceará, Brazil. It lies at the geographical coordinated of $3^{\circ} 44^{\prime} 33.44^{\prime \prime} S$ latitude and $38^{\circ} 34^{\prime} 42.54^{\prime \prime} \mathrm{W}$ longitude, and at an average altitude of 15.5 meters above sea level. The local climate is $A w$ type (tropical with dry winter), according to the Köppen's classification. The rainy season occurs from January to March and has average annual rainfall of $1338 \mathrm{~mm}$, and average ambient temperature between 26 and $28^{\circ} \mathrm{C}$.

\section{Experimental animals}

From a total of 15 reproducers, 10 halfbreed males with no defined standard breed were selected based on their sperm picture. Every animal was evaluated, but only those with no ideal characteristics for reproduction were chosen. The criteria for this selection were recommended by the Manual of the Brazilian College of Animal Reproduction (CBRA, 2013). Four adult lambs were selected, averaging 8 years of age and $45 \mathrm{~kg}$. Six adult goats were also selected, averaging 7 years of age and $45 \mathrm{~kg}$. Animals were kept in individual stalls and were given elephant grass (Pennisetum purpureum Schum) roughage as base feeding along with $18 \%$ crude protein to fulfill NRC (2007) recommendations. Water and mineral salt were also provided ad libitum.

Before selection, all individuals were submitted to clinical and laboratory exams to guarantee health and to verify adaptability to the imposed conditions. No sick animals or animals with any indication of physical or laboratory pathologies, in any of their systems, were selected. 


\section{Previous andrological evaluation}

In the week prior to treatment, the selected reproducers were submitted to clinical-andrological exams and spermograms. Samples were collected every 72 hours using the electroejaculation method, which consists of a $12 \mathrm{~V}$ device sending stimulation currents between $200 \mathrm{~mA}$ and $300 \mathrm{~mA}$ at intervals of 2 to 5 seconds. During the experiment, before each sample collection, animals went through quick clinical evaluations and their scrotal circumferences were measured. All semen samples were evaluated for macroscopic aspects (volume, color, and aspect) and microscopic aspects (mass motility, vigor, and percentage of mobile sperm). Kinetic sperm parameters were measured by an experienced evaluator who had worked with semen assessments for 27 years.

According to CBRA, adequate semen parameters for both goats and lambs are sperm motility, equal or superior to $80 \%$; vigor, higher or equal to 3 ; and percentage of morphologically normal sperm, equal to or higher than $80 \%$. For lambs, the acceptable volume is about 0.5 to $3 \mathrm{~mL}$; mass motility, equal or higher than 3; sperm concentration, from 1 to 3 billion per $\mathrm{mL}$; and a total of 3 to 5 billion sperm per ejaculate. The same parameters for goats are volume, from 0.5 to $1.5 \mathrm{ml}$; mass motility, equal to or higher than 4; concentration, between 2 and 5 billion sperm per $\mathrm{ml}$; and a total of 3 to 5 billion sperm per ejaculate.

Sperm concentration was measured in a Neubauer chamber, using 1:400 dilution in a formalin-saline solution. Microscopic slides to analyze morphological alterations were prepared using bromophenol as a blue dye (MEDEIROS et al., 2011). Sperm morphology and the percentages of major and minor defects were evaluated by counting 200 sperm cells per slide for each ejaculate, according to the Blom classification (CBRA, 2013).

\section{Drug administration}

Flunixin Meglumine was applied to all animals intramuscularly. The first application (D0) occurred after the third previous sample of semen was collected (Figure 1).

Figure 1. Diagram of the experiment, containing events that occurred to both goats and lambs.

\begin{tabular}{|c|c|c|c|c|c|c|c|}
\hline Week & Monday & Tuesday & Wednesday & Thursday & Friday & Saturday & Sunday \\
\hline $1^{\mathrm{st}}$ & $\mathrm{C}$ & & & $\mathrm{C}$ & & & \\
\hline $2^{\text {nd }}$ & $\mathrm{D} 0=\mathrm{C}$ e $\mathrm{A}$ & & $\mathrm{D} 2=\mathrm{C}$ e $\mathrm{A}$ & & $\mathrm{D} 4=\mathrm{C}$ e $\mathrm{A}$ & & \\
\hline $3^{\text {rd }}$ & & & & & & & \\
\hline $4^{\text {th }}$ & & & $\mathrm{D} 16=\mathrm{A}^{\prime}$ & & & & \\
\hline $5^{\text {th }}$ & $\mathrm{D} 21=\mathrm{C}$ & & $\mathrm{D} 23=\mathrm{A}^{\prime}$ & & & & \\
\hline $6^{\text {th }}$ & $\mathrm{D} 28=\mathrm{C}$ & & $\mathrm{D} 30=\mathrm{A}^{\prime}$ & & & & \\
\hline $7^{\text {th }}$ & $\mathrm{D} 35=\mathrm{C}$ & & & & & & \\
\hline $8^{\text {th }}$ & & & & & & & \\
\hline $9^{\text {th }}$ & $\mathrm{D} 49=\mathrm{C}$ & & & & & & \\
\hline $10^{\text {th }}$ & & & & & & & \\
\hline $11^{\text {th }}$ & $\mathrm{D} 63=\mathrm{C}$ & & & & & & \\
\hline
\end{tabular}


Administration of the drug occurred at two time periods: first, each animal received a $2.2 \mathrm{mg}$ dose of Flunixin Meglumine per kg of live weight every 48 hours (D0, D2, and D4). Twelve days after the third application (D16), the second period of the treatment began, in which three $1.1 \mathrm{mg}$ per $\mathrm{kg}$ of live weight doses were applied to each reproduction animal in a one-week interval (D16, D23, and D30), which intended to maintain the results reached.

\section{Post-treatment sperm collection and assessment}

Sample collection was resumed on D21, following the same evaluation and collection methods used before Flunixin Meglumine applications.

Five samples, always on Mondays (D21, D28, D35, D49, and D63), were acquired after treatment began to verify the seminal picture of the animals. The first three sample collections coincided with the period in which applications of $1.1 \mathrm{mg} \mathrm{Kg}^{-1}$ of live weight were being applied. The collective performance was monitored and assessed so the term of drug effect on seminal quality could be measured. The time interval between collections on D35 and D49 was two weeks long, considered the second period after treatment, and no drug applications happened during this time.

\section{Statistical analysis}

For this experiment, a systematic sampling by senility was used to select animals with inferior sperm characteristics than those recommended by CBRA (2013) so male lambs and goats could be andrologically evaluated.

Experimental delineation consisted of a $2 \times 4$ factorial, in which two species were studied (goat and lamb) with evaluation of seminal characteristics data at three different periods: before drug application, at the first period after application (from D21 to D35) and in the second period (from D49 to D63).

The data, expressed in averages and standard mistakes, were submitted to a Shapiro-Wilk normality test. Those showing non-normal distribution, even after transformed $(\log (x+1))$, were analyzed by the Kolmogorov-Smirnov nonparametric test. Data in which normality was achieved were assessed by ANOVA testing (at 5\% probability) and, when significant, comparisons between periods within each species were made by the Tukey's test.

\section{Results and Discussion}

The 17-day period, between the last day of treatment (D4) and the first post-treatment collection (D21), was defined with the intention of providing enough time for sperm already present in the tail of the epididymis to complete transit in the organ, allowing the evaluation to be performed on sperms in seminiferous tubules during treatment. According to Jones e Dacheux (2007), the literature states the maintenance period of sperm cells in epididymal ducts is up to 16.4 days long when transformations of maturity occur.

Parameters of mass motility (MM), the percentage of mobile sperm (\%) and vigor were evaluated (Table 1) and show a considerable increase in all aspects from D21 to D35, with significant variation $(\mathrm{P}<0.05)$, regardless of the species. In Lambs, this improvement was no longer sustained after treatment. In goats, on the other hand, improvement remained after drug application, with exception to sperm motility, which decreased significantly. 
Table 1. Sperm motility parameters in goat and lamb males submitted to Flunixin Meglumine treatment.

\begin{tabular}{ccccc}
\hline Species & Periods & MM (0-5) & $\begin{array}{c}\text { Motility percentage } \\
\text { of mobile sperm (\%) }\end{array}$ & Vigor (0-5) \\
\hline \multirow{3}{*}{ Lamb } & Before & $2.06 \pm 0.67^{\mathrm{a}}$ & $36.67 \pm 7.26^{\mathrm{a}}$ & $2.39 \pm 0.36^{\mathrm{a}}$ \\
& D21 - D35 & $3.55 \pm 0.29^{\mathrm{b}}$ & $61.00 \pm 2.33^{\mathrm{b}}$ & $3.65 \pm 0.17^{\mathrm{b}}$ \\
& D49-D63 & $2.58 \pm 0.68^{\mathrm{a}}$ & $36.67 \pm 8.03^{\mathrm{a}}$ & $2.75 \pm 0.38^{\mathrm{a}}$ \\
\hline \multirow{3}{*}{ Goats } & Before & $2.50 \pm 0.31^{\mathrm{a}}$ & $48.82 \pm 6.16^{\mathrm{a}}$ & $2.82 \pm 0.22^{\mathrm{a}}$ \\
& D21 - D35 & $3.50 \pm 0.21^{\mathrm{b}}$ & $65.28 \pm 2.98^{\mathrm{b}}$ & $3.72 \pm 0.14^{\mathrm{b}}$ \\
& D49-D63 & $3.83 \pm 0.19^{\mathrm{b}}$ & $58.75 \pm 5.91^{\mathrm{a}}$ & $3.79 \pm 0.18^{\mathrm{b}}$ \\
\hline \multirow{3}{*}{ Regardless of species } & Before & $2.35 \pm 0.30^{\mathrm{a}}$ & $44.61 \pm 4.80^{\mathrm{a}}$ & $2.67 \pm 0.19^{\mathrm{a}}$ \\
& D21 - D35 & $3.52 \pm 1.17^{\mathrm{b}}$ & $63.75 \pm 2.10^{\mathrm{b}}$ & $3.70 \pm 0.10^{\mathrm{b}}$ \\
& D49-D63 & $3.42 \pm 0.29^{\mathrm{b}}$ & $51.39 \pm 5.27^{\mathrm{a}}$ & $3.44 \pm 0.21^{\mathrm{b}}$ \\
\hline
\end{tabular}

*Lowercase letters indicate statistical variation in the Tukey test $(\mathrm{p}<0.05)$ within each sub-column.

When individually evaluated, species mass motility and vigor parameters remained similar in both periods after treatment, with a significant reduction $(\mathrm{p}<0.05)$ only in motility. Results for sperm motility (MM, mobile \% and strength) after the drug application are close to what is considered "acceptable" by the CBRA (2013) for seminal quality evaluations in male lamb and goats.

Scrotal circumference showed no significant alterations at the different times in either for species, which demonstrates the lack of influence of the drug on this parameter during experimentation periods (Table 2). Goat results obtained in the present study are similar to those found by other authors studying native goats from the northeast region of Brazil (SANTOS; SIMPLÍCIO, 2000). However, for lambs, the results obtained in this study are inferior to those obtained by Maia et al. (2011) in half-breeds.

Semen volume of goats showed a significant increase $(\mathrm{p}<0.05)$ between D21 and D35, and between D49 and D63. This increase may be due to the behavior of this species during the electroejaculation collecting process since they feel more discomfort during the process, which can interfere with drug activity. The volume increase is probably due to a higher quantity of secretion in the accessory glands, which may have occurred when electrostimulation was performed (RODRIGUES, 1997). Results from the first moment post-treatment are close to those found by Santos and Simplício (2000) in goats and by Maia et al. (2011) in lambs and were in agreement with CBRA recommendations (2013) for andrological exams in these species. 
Table 2. Scrotal circumference (SC) and quantitative sperm parameters of male goats and lambs, submitted to Flunixin Meglumine treatment.

\begin{tabular}{cccccc}
\hline Species & Periods & SC $(\mathrm{cm})$ & Volume $(\mathrm{mL})$ & Concentration $\left(10^{6} \mathrm{Sptz} / \mathrm{mL}\right)$ & Total $\left(10^{6} \mathrm{Sptz}\right)$ \\
\hline \multirow{4}{*}{ Lamb } & Before & $30.39 \pm 0.64$ & $0.53 \pm 0.06$ & $1028.89 \pm 429.81^{\mathrm{a}}$ & $608.67 \pm 262.10^{\mathrm{a}}$ \\
& D21-D35 & $30.03 \pm 0.46$ & $0.86 \pm 0.17$ & $3028.00 \pm 612.94^{\mathrm{b}}$ & $2846.00 \pm 725.86^{\mathrm{b}}$ \\
& D49-D63 & $30.08 \pm 0.55$ & $0.52 \pm 0.05$ & $3195.00 \pm 1327.30^{\mathrm{b}}$ & $1807.33 \pm 857.22^{\mathrm{b}}$ \\
\hline \multirow{3}{*}{ Goats } & Before & $26.52 \pm 0.68$ & $0.77 \pm 0.09^{\mathrm{a}}$ & $716.91 \pm 204.86^{\mathrm{a}}$ & $553.74 \pm 152.10^{\mathrm{a}}$ \\
& D21-D35 & $26.83 \pm 0.68$ & $0.72 \pm 0.06^{\mathrm{a}}$ & $186.67 \pm 26.61^{\mathrm{b}}$ & $136.78 \pm 21.97^{\mathrm{b}}$ \\
& D49-D63 & $26.75 \pm 0.96$ & $1.12 \pm 0.17^{\mathrm{b}}$ & $650.21 \pm 127.35^{\mathrm{a}}$ & $603.54 \pm 94.29^{\mathrm{a}}$ \\
\hline \multirow{2}{*}{ Regardless } & Before & $27.86 \pm 0.61$ & $0.69 \pm 0.07$ & $824.90 \pm 197.24$ & $572.75 \pm 131.6^{\mathrm{a}}$ \\
of species & D21-D35 & $27.97 \pm 0.55$ & $0.77 \pm 0.07$ & $1201.43 \pm 337.14$ & $1104.56 \pm 354.02^{\mathrm{b}}$ \\
& D49-D63 & $27.86 \pm 0.76$ & $0.92 \pm 0.13$ & $1498.47 \pm 514.18$ & $1004.81 \pm 307.93^{\mathrm{b}}$ \\
\hline
\end{tabular}

*Lowercase letters indicate statistical variation in the Tukey test $(\mathrm{p}<0.05)$ within each sub-column.

Sperm concentration and total number of sperm per ejaculate presented significant increase $(p<0.05)$ between the period before and both periods after application, but reduced once again after the second moment, which probably happened because male goats had presented an important increase in seminal plasma quantity during this period, probably due to the collection method (RODRIGUES, 1997), which resulted in lower sperm concentration.

Both species significantly increased $(\mathrm{p}<0.05)$ percentage of normal sperm between the period before and the period after the first treatment. (Table 3). However, the percentage of normal lamb sperm showed significant reduction between D49 and D63, coming close to results presented before drug application. In goats, at the period between D49 and D63, the percentage of normal cells showed no significant decrease, rather stayed close to the numbers shown between D21 and D35, which suggests prolonged drug activity for this parameter in goats. This also shows the same evolution seen in sperm motility parameters.
Major defects were significantly reduced in both species after Flunixin Meglumine applications. The reduction was maintained until the period between D49 and D63 when drug applications ceased. According to Moreira et al. (2001), these defects are mainly originated at a testicular level and the obtained results suggest this drug might act in the final spermatogenesis phases. This may also explain the maintenance of the condition even after interrupting drug reinforcements.

Percentage of minor defects significantly reduced $(p<0.05)$ between the period before and the first period after the application. However, results obtained from all evaluations increased once again when applications ceased. Therefore, minor defects reduction at the period between D21 and D35 was followed by an increase during the period from D49 to D63. These results are similar when analyzed without regarding the species. According to Moreira et al. (2001), minor defects can be primarily originated in the epididymis, therefore, at the end of treatment, improvement can be interrupted and continuous flow of sperm may present new increase in defect proportions. 
Table 3. Percentage of normal sperm, minor defects and major defects of semen of male goats and lambs, submitted to Flunixin Meglumine treatment.

\begin{tabular}{ccccc}
\hline Species & Periods & Normal (\%) & Major defects (\%) & Minor defects (\%) \\
\hline \multirow{3}{*}{ Lamb } & Before & $67.11 \pm 2.38^{\mathrm{a}}$ & $9.89 \pm 1.15^{\mathrm{a}}$ & $23.00 \pm 2.40^{\mathrm{a}}$ \\
& D21 - D35 & $85.95 \pm 1.84^{\mathrm{b}}$ & $2.10 \pm 0.76^{\mathrm{b}}$ & $11.95 \pm 2.00^{\mathrm{b}}$ \\
& D49-D63 & $68.75 \pm 5.18^{\mathrm{a}}$ & $3.17 \pm 0.81^{\mathrm{b}}$ & $28.08 \pm 4.67^{\mathrm{a}}$ \\
\hline \multirow{3}{*}{ Goats } & Before & $73.74 \pm 1.82^{\mathrm{a}}$ & $6.59 \pm 0.61^{\mathrm{a}}$ & $19.68 \pm 1.60^{\mathrm{a}}$ \\
& D21-D35 & $87.47 \pm 3.27^{\mathrm{b}}$ & $1.64 \pm 0.34^{\mathrm{b}}$ & $10.89 \pm 3.22^{\mathrm{b}}$ \\
& D49-D63 & $84.79 \pm 0.73^{\mathrm{b}}$ & $1.83 \pm 0.32^{\mathrm{b}}$ & $13.38 \pm 0.76^{\mathrm{b}}$ \\
\hline \multirow{2}{*}{ Regardless of } & Before & $71.44 \pm 1.60^{\mathrm{a}}$ & $7.73 \pm 0.64^{\mathrm{a}}$ & $20.83 \pm 1.34^{\mathrm{a}}$ \\
species & D21-D35 & $86.93 \pm 2.18^{\mathrm{b}}$ & $1.80 \pm 0.34^{\mathrm{b}}$ & $11.27 \pm 2.17^{\mathrm{b}}$ \\
& D49-D63 & $79.44 \pm 2.49^{\mathrm{c}}$ & $2.28 \pm 0.36^{\mathrm{b}}$ & $18.28 \pm 2.28^{\mathrm{a}}$ \\
\hline
\end{tabular}

*Lowercase letters indicate statistical variation in the Tukey test $(\mathrm{p}<0.05)$ within each sub-column.

The post-treatment results shown here indicate a significant improvement of seminal characteristics related to sperm motility and quantitative numbers of semen, and to normal sperm and minor and major defects. Seminal characteristics were recovered from unsatisfactory to nearly accepted values according to CBRA (2013).

Flunixin meglumine is a potent nonsteroidal anti-inflammatory commonly used in the treatment of inflammatory processes of several origins (TASAKA, 2014), however, up to now, there was no knowledge regarding the beneficial activity it may cause on male seminal quality. In the reproductive sphere, its use is reported in studies related to female bovine, reducing $\mathrm{PGF}_{2 \alpha}$ production, increasing pregnancy rates in heifers (GUZELOGLU et al. 2007 ) and increasing in vitro production of embryos (KIM et al. 2014).

In males, we found only one citation in which this drug was used for lambs and it resulted in prostaglandin (PGE) reduction and increase of acrosomal reaction in sperm (ARCHBALD et al. 1990). However, the authors reported no results of the activity on seminal characteristics of sperm motility.

The positive effects of Flunixin Meglumine were observed accidentally for the first time when researchers were treating animals with arthritis and submitted them to semen collection in an artificial vagina. In such study, improvements in seminal characteristics were repeatedly observed. Thus, throughout time, we obtained clinical experience in fertility recovery of males going through senility, as well as recovery of males under thermal testicular stress impact due to high ambient temperatures. Since the use of this drug improved fertility of the males cited above, we decided to elaborate this research.

The beneficial effect can be explained based on the biochemical activity of Flunixin Meglumine. Phospholipases and prostaglandins are known to be intimately connected to inflammatory and degenerative processes and to increase concentrations in these situations (HUDSON et al. 2016; YANG et al., 2017). In the reproductive field, the inflammatory process of the endometrium in postpartum can be exemplified: the COX-2 enzyme is responsible for mobilization of arachidonic acid for PGE production (HUDSON et al. 2016).

Similar activity may take place in the epididymis, involving an inflammatory or local degenerative process, which begins cascade activation for PGE formation by phospholipase A1 activity, which in turn, degrades membrane phospholipids of epididymal cells and releases arachidonic acid, which, through COX-2 activity, is transformed 
into prostaglandins (HUDSON et al. 2016). COX2 inhibition using Flunixin Meglumine reduces the concentration of prostaglandins in the epididymis.

The epididymis is an important forerunner organ for fertilization capability in sperm and provision of motility, due to the production of several proteins throughout it (DACHEUX; DACHEUX; DRUART, 2016). Therefore, in degenerative processes due to senility or other damage, this organ provides an unfavorable environment for a full production of viable sperm. Flunixin Meglumine activity in the epididymis enables the formation of a satisfactory environment for sperm viability, which explains, in this study, the improvement in the seminal quality of animal after drug application.

\section{Conclusions}

Based on the "in vitro" evaluation results of this study, we may report on the beneficial impact of Flunixin Meglumine on seminal parameters of male goats and lambs containing unfavorable sperm frames.

This benefit takes place mainly in the improvement of motility parameters (mass motility, mobile cell $\%$ and strength), as well as in parameters linked to male fertility, such as increase of normal cells and reduction of altered sperms.

Therefore, this drug can be indicated for male adult goats and lambs with testicular injuries or for reproducers facing a decline in seminal quality due to advanced age. Additional studies are required to evaluate "in vivo", i.e. after natural mount or artificial insemination, the fertility of males treated with this drug.

\section{Acknowledgements:}

Special thanks to Professor Ph.D. Pedro Zione, who is responsible for the Lamb and Goat sector of the Federal University of Ceará, for providing the animals used in this experiment.

\section{References}

AKE-LOPEZ, R.; SEGURA-CORREA, J. C.; QUINTALFRANCO, J. Effect of flunixin meglumine on the corpus luteum and possible prevention of embryonic loss in Pelibuey ewes. Small Ruminant Research, Amsterdam, v. 59, n. 1, p. $83-87,2005$.

ALVES, M. B. R.; ARRUDA, R. P.; BATISSACO, L.; FLOREZ-RODRIGUEZ, S. A.; OLIVEIRA, B. M. M.; TORRES, M. A.; RAVAGNANI, G. M.; LANÇONI, R.; ALMEIDA, T. G.; STORILLO, V. M.; VELLONE1, V. S; FRANCI, C. R.; THOMÉ, H. E.; CANELLA, C. L.; ANDRADE, A. F. C.; CELEGHINI, E. C. C. Low-level laser therapy to recovery testicular degeneration in rams: effects on seminal characteristics, scrotal temperature, plasma testosterone concentration, and testes histopathology. Lasers in Medical Science, London, v. 31, n. 4, p. 695-704, 2016.

ARCHBALD, L.; GRONWALL, R. R.; PRITCHARD, E. L.; TRAN, T. Acrosome reaction and concentration of prostaglandin E2 in semen of rams treated with flunixin meglumine (Banamine). Theriogenology, Stoneham, v. 33, n. 2, p. 373-383, 1990.

ARMENGOL, M. F. L.; SABINO, G. A.; FORQUERA, J. C.; CASA, A. de; AISEN, E. G. Sperm head ellipticity as a heat stress indicator in Australian Merino rams (Ovis aries) in Northern Patagonia, Argentina. Theriogenology, Stoneham, v. 83, n. 4, p. 553-559, 2015.

CARDOSO, R. C. Efeito do flunixin meglumine na duração da fase luteal e na taxa de prenhez de receptoras de embriões bovinos. 2009. Dissertação (Mestrado) Universidade Estadual Paulista, Faculdade de Medicina Veterinária e Zootecnia, Botucatu.

COLÉGIO BRASILEIRO DE REPRODUÇÃO ANIMAL - CBRA. Manual para exame andrológico e avaliação de sêmen animal. 3. ed. Belo Horizonte: CBRA, 2013. $37 \mathrm{p}$.

CEBI ŞEN, C; AKCAY, E. The effect of oxytocin and prostaglandin hormones added to semen on stallion sperm quality. Turkish Journal of Veterinary and Animal Sciences, Ankara, v. 39, n. 6, p. 705-708, 2015.

DACHEUX, J. L.; DACHEUX, F.; DRUART, X. Epididymal protein markers and fertility. Animal Reproduction Science, Amsterdam, v. 169, p. 76-87, 2016.

FAYED, A. H. A. Effect of prostaglandin $F_{2 \alpha}$ and methylxanthines on enzymic release of bull epididymal spermatozoa in vitro. Contraception, Washington, v. 53, n. 3, p. 181-184, 1996. 
GUZELOGLU, A.; ERDEM, H.; SARIBAY, M. K.; THATCHER, W. W.; TEKELI, T. Effect of the administration of flunixin meglumine on pregnancy rates in Holstein heifers. Veterinary Record, Birmingham, v. 160, n. 12, p. 404-406, 2007.

HUDSON, C. A.; MCARDLE, C. A.; LÓPEZ BERNAL, A. Steroid receptor co-activator interacting protein (SIP) mediates EGF-stimulated expression of the prostaglandin synthase COX2 and prostaglandin release in human myometrium. Molecular Human Reproduction, Oxford, v. 22 , n. 7, p. 512-525, 2016.

JONES, R. C.; DACHEUX, J. L. Physiology of the epididymis. In: KANDEL, F. R.; SWERDLOFF, R. S.; PRIOR, J. L. Male reproductive dysfunction: pathophysiology and treatment. Nova York: Informa Healthcare, 2007. cap. 6, p. 71-80.

KIM, S. S.; BANG, J. I.; FAKRUZZAMAN, M.; LEE, K. L.; KO, D. H.; GHANEM, N.; WANG, Z.; KONG, I. $\mathrm{K}$. Effects of flunixin meglumine and prostaglandin F2 $\alpha$ treatments on the development and quality of bovine embryos in vitro. Reproduction in Domestic Animals, Berlin, v. 49, n. 6, p. 957-963, 2014.

LYMBEROPOULOS, A. G.; TSAKMAKIDIS, I. A.; KHALIFA, T. A. A. Effect of ram age on structural and functional competence of frozen-thawed spermatozoa in dairy sheep. Reproduction in Domestic Animals, Berlin, v. 45, n. 4, p. 572-578, 2010.

MAIA, M. S.; MEDEIROS, I. M.; LIMA, C. A. C. Características reprodutivas de carneiros no Nordeste do Brasil: parâmetros seminais. Revista Brasileira de Reprodução Animal, Belo Horizonte, v. 35, n. 2, p. 175179, 2011.

MANDIKI, S. N. M.; DERYCKE, G.; BISTER, J. L.; PAQUAY, R. Influence of season and age on sexual maturation parameters of Texel, Suffolk and Ile-de-France rams: 1 . Testicular size, semen quality and reproductive capacity. Small Ruminant Research, Amsterdam, v. 28, n. 1, p. 67-79, 1998.

MARLEY, P. B.; MORRIS, S. R.; WHITE, I. G. Concentration of prostaglandins $\mathrm{E}$ and $\mathrm{F}$, fructose and glycerylphosphorylcholine in ram semen obtained by electro-ejaculation or artificial vagina and in vesicular fluid. Theriogenology, Stoneham, v. 8, n. 1, p. 33-43, 1997.
MEDEIROS, A. A.; ARAUJO, A. A.; MOURA, A. A. A.; CAVALCANTE, J. M. M.; FIGUEIREDO, E. L.; RODRIGUES, L. F. S. Utilização do azul de bromofenol conservado a $4^{\circ} \mathrm{C}$ e $29^{\circ} \mathrm{C}$, como método de coloração vital para avaliação do espermatozoide ovino. Ciências Agrárias, Manaus, v. 46, n. 1, p. 287-297, 2011.

MOREIRA, E. P.; MOURA, A. A.; ARAÚJO, A. A. Efeitos da insulação escrotal sobre a biometria testicular e parâmetros seminais em carneiros da raça santa inês criados no Estado do Ceará. Revista Brasileira de Zootecnia, Viçosa, v. 30, n. 6, p. 1704-1711, 2001.

NUTRIENT REQUIREMENTS OF SMALL RUMINANTS - NRC. Sheep, goats, cervids, and New world camelids. National Academy Press, Washington, DC, 2007. $362 \mathrm{p}$.

PALERMO-NETO, J.; ARRUDA, R. P.; MADUREIRA, E. H. Prostaglandinas. In: SPINOSA, H. S.; GÓRNIAK, S. L.; BERNARDI, M. M. Farmacologia aplicada à medicina veterinária. 5 . ed. Rio de Janeiro: Guanabara Koogan, 2014. cap. 20, p. 230-244.

RODRIGUES, L. F. S. Efeito do método de colheita sobre os aspectos fisicos, morfológicos e bioquímicos do sêmen de caprinos mestiços e ovinos deslanados da raça Santa Inês criados no Estado do Ceará. 1997. Dissertação (Mestrado) - Faculdade de Veterinária do Ceará, Universidade Estadual do Ceará, Fortaleza.

SANTOS, D. O.; SIMPLÍCIO, S. A. parâmetros escrototesticulares e de sêmen em caprinos adultos submetidos à insulação escrotal. Pesquisa Agropecuária Brasileira, Brasília, v. 35, n. 9, p. 1835-1841, 2000.

TASAKA, A. C. Anti-inflamatórios não esteroidais. In: SPINOSA, H. S.; GÓRNIAK, S. L.; BERNARDI, M. M. Farmacologia aplicada à medicina veterinária. 5. ed. Rio de Janeiro: Guanabara Koogan, 2014. cap. 21, p. 245-260.

YANG, G.; DENG, Q.; FAN, W.; ZHANG, Z.; XU, P.; TANG, S.; WANG, P.; WANG, J.; YU, M. Cyclooxygenase-2 expression is positively associated with lymph node metastasis in nasopharyngeal carcinoma. PloS one, San Francisco, v. 12, n. 3, p. 1-18, 2017. 